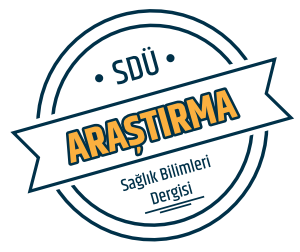

Sdü Sağlık Bilimleri Enstitüsü Dergisi / Cilt 8 Sayı 2 / 2017

\title{
Upper Airway Morphology and Head Posture in Healthy Men and Women
} Sağlıklı Erkek ve Kadınlarda Üst Hava Yolu Morfolojisi ve Baş Postürü

\author{
Aynur Medine Şahin Sağlam¹, Neslihan Ebru Şenışık² \\ ${ }^{1}$ Incident Dental Clinic, Isparta, Turkey. \\ ${ }^{2}$ Suleyman Demirel University Faculty of Dentistry Department of Orthodontics, Isparta, Turkey.
}

\begin{abstract}
Objective: The aim of our study was to investigate morphological differences in the upper airway of healthy men and women on lateral cephalometric radiographs.

Material-Method: In our study, we evaluated 76 lateral cephalometric radiographs of adult subjects (38 men and 38 women) with class I skeletal pattern taken in natural head posture. In order to determine natural head posture, we used self-balance position, which was transferred to the cephalostat by means of a fluid level device. All lateral cephalograms were traced manually. The effect of gender on upper airway morphology and natural head posture was evaluated using Student's t-test.
\end{abstract}

Results: We found that measurements used in the determination of natural head posture were similar for men and women. Linear measurements regarding the position of bony structures (MP-AH, AH-AH1, C3ia-AH, and Ba-C3ia), soft tissue (PNS-P, MPT, PNS-Et, TGL, and TGH), tongue area, soft palate area, and oropharynx area were statistically significant, with respect to gender.

Conclusions: The hyocervical relation is affected by gender differences whereas hyomandibular relation is well balanced in subjects with normal occlusion and class I skeletal pattern and was not affected by gender. Natural head posture was not affected by gender differences. Tongue area, soft palate area, and oropharyx area are larger in men. However, no statistically significant differences were observed between genders for nasopharynx and hypopharyx areas.

Keywords: Upper Airway, Natural Head Posture, Nasopharyngeal Area

\section{Özet}

Amaç: $\mathrm{Bu}$ çalışmanın amacı lateral sefalometrik radyograflar üzerinde sağlıklı erkek ve kadınların üst hava yolu morfolojisindeki ve baş postüründeki farklılıkları incelemektir.

Materyal-Metot: Çalışmamızda doğal baş postüründe alınmış, 38 erkek, 38 kadın toplam 76 erişkin bireye ait lateral sefalometrik radyograf değerlendirilmiştir. Doğal baş postürünün belirlenmesinde self-balans pozisyonu kullanılmıştır. Tüm lateral sefalometrik radyograflar manuel olarak çizilmiştir. Üst hava yolu ve doğal baş postürü üzerine cinsiyetin etkisi Student's t-test kullanılarak analiz edilmiştir.

Bulgular: Bu çalışmanın sonuçlarına göre doğal baş postürü kadınlarda ve erkeklerde istatistiksel olarak benzerdir. ( $p>$ 0,05) Kadın ve erkekler arasındaki farklılığın belirlenmesi için yapılan ve kemik yapıların pozisyonunun belirlenmesinde kullanılan lineer ölçümler (MP-AH, AH-AH1, C3ia-AH, ve Ba-C3ia), yumuşak doku ölçümleri (PNS-P, MPT, PNS-Et, TGL, TGH), dil alanı, yumuşak damak alanı ve orofarenks alanı istatistik olarak farklıdır. $(\mathrm{p}<0,05)$

Sonuç: Hyoservikal ilişki cinsiyet farklılığından etkilenirken, hyomandibuler ilişkiler iskeletsel sınıf I paterne sahip erkek ve kadınlarda dengededir ve cinsiyetten etkilenmemektedir. Doğal baş postürü de cinsiyet farklılığından etkilenmemektedir. Dil alanı, yumuşak damak alanı ve orofarenks alanı erkeklerde daha geniştir. Nazofarenks ve hipofarenks alanı ise kadın ve erkeklerde benzerdir.

Anahtar kelimeler: Üst havayolu, Baş Postürü, Nazofaringeal Alan

\section{Introduction}

The soft tissue of the oral and nasal pharynx is potentially related to the size and shape of the oral and nasal airway and obstructive sleep apnea (OSA), which is a common disorder characterized by repetitive episodes of upper airway narrowing or collapse (1). Obstructive sleep apnea is more common in men than women even though women with OSA tend to be more obese and have smaller upper airways than men (2). This gender difference in the prevalence of OSA has not been explained adequately on the basis of upper airway size (3).

The upper airway is divided into 3 parts: nasopharynx, oropharynx, and laryngopharynx. The nasopharynx and the oropharynx have significant locations and functions as they form a part of a unit in which deglutition and respiration are carried out. Nasal obstruction secondary to hypertrophied inferior turbinates, hypertrophy of the faucial tonsils, and the adenoid pad can result in loud snoring, chronic 
mouth breathing, OSA, sleep disorders, excessive daytime sleepiness (4), and postural changes. Open mandible posture, inadequate lip structure, forward and downward positioning of the tongue, extensive neck posture, long face syndrome, and adenoid face can occur (5-7). A reciprocal influence can be expected between upper airway structures and dentofacial pattern. In many studies, significant relationships between upper airway structures and dentofacial and/or craniofacial structures were reported (7).

Several techniques (cineradiography, fibroscopy, acoustic reflection, flouroscopy, computed tomography, and magnetic resonance imaging) have been used to visualize and assess upper airway size and function (8-9). Lateral cephalometry is the most commonly used technique because of its relative simplicity, accessibility, low-cost, and minimal radiation exposure (9). Cephalometry is used less often and usually in clinical research to assess cranio-cervical angulations, pharyngeal relationships, soft palate dimensions, and hard tissue abnormalities $(10,11)$.

Studies have demonstrated that patients with OSA had extended head posture, reduced oropharyngeal airway dimensions, enlarged tongues and soft palate, and low position of the hyoid bone and tongue (1, 9-12). Gender differences amongst the majority of OSA patients have not been explained adequately and it has been suggested that risk factors and the mechanism of OSA may differ between men and women (13). However, these studies examined primarily the upper airway in OSA patients. Few studies have examined upper airway dimensions in normal subjects and their associated gender differences $(8,11,14,15)$. Comparative assessment of head posture and upper airway dimensions in adult male and female subjects with normal vertical dimensions and class I skeletal pattern can provide a standard norm for determining pharyngeal airway structure and gender differences amongst OSA cases.

The purpose of our study is to investigate head posture and upper airway dimensions on cephalometric radiographs of healthy adult male and female subjects with skeletal class I pattern. The null hyphothesis was that there are no statistically significant differences between men and women with regards to head posture and upper airway dimensions.

\section{Material-Method}

In our retrospective study, inclusion criteria for participants were (a) all permanent teeth present and fully erupted except for the third molar teeth, (b) skeletal class I pattern with ideal occlusion, (c) parents of Turkish origin, (d) no visual and hearing disorders, (e) no orthodontic treatment and orthognatic surgery, and (f) no burns, injuries, or cicatrix tissue in the head and neck regions, ( $\mathrm{g}$ ) no breathing and swallowing disorders, and (h) chronologic age $\geq 18$ years.

In our study, 76 cephalometric radiograph films of 38 men and 38 women in natural head posture were evaluated. In the postural recording method, radiographs were taken with the subject standing in orthoposition (i.e., natural head posture as originally defined by Mølhave (16) as the intentional

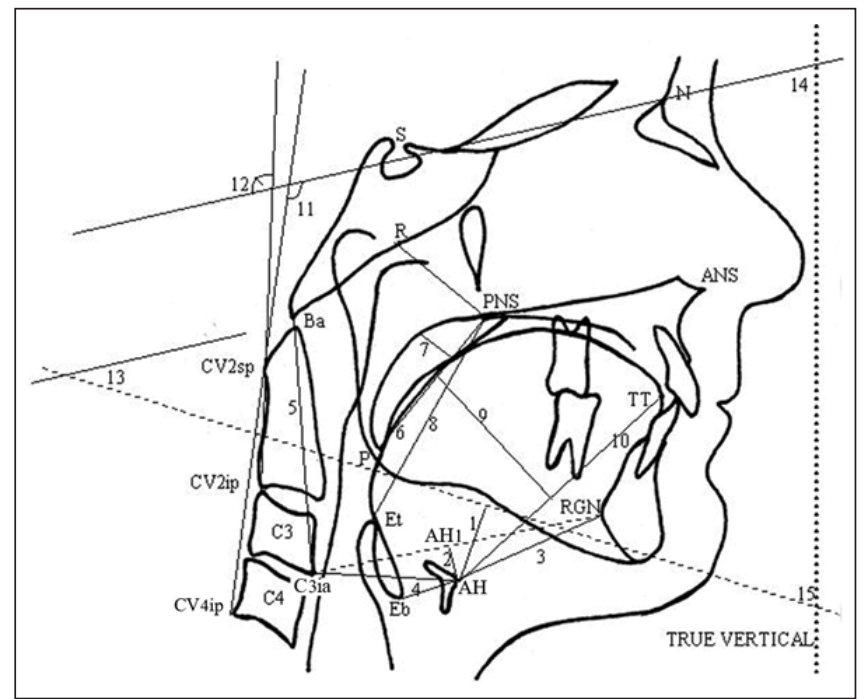

Figure 1. The landmarks, linear and angular measurements

(1) MP-AH, linear distance along a perpendicular from $\mathrm{AH}$ to the mandibular plane; (2) $\mathrm{AH}-\mathrm{AH} 1$, linear distance between $\mathrm{AH}$ and perpendicular to the line C3ia to the RGN (retrognathion); (3) $\mathrm{AH}$ RGN, linear distance between $\mathrm{AH}$ and RGN; (4) C3ia-AH, linear distance between $\mathrm{C} 3 \mathrm{ia}$ and $\mathrm{AH}$; (5) Ba-C3ia, linear distance between Ba and C3ia; (6) PNS-P, linear distance between PNS and P; (7) MPT, the maximum thickness of the soft palate measured on a line perpendicular to the PNS-P line; (8) PNS-Et, linear distance between PNS and Et; (9) TGL, the tongue length-the linear distance between $\mathrm{Eb}$ and TT; (10) TGH, the tongue height- a line perpendicular to the Eb-TT line; (11) CVTS, the angle Eb and Ti, (10) TGH, he tongue hight- a lise construted by an extension of the line CV 2 sp to CV4ip plane and the SN plane; (12) OPTS, the angle CN the SN pla ane

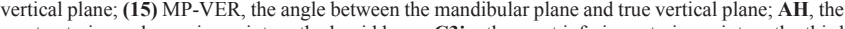
most anterior and superior point on the hyoid bone; C3ia, the most inferior anterior point on the third cervical vertebrae; RGN, the most inferior posterior point on the mandibular symphysis; Ba, basion; PNS, posterior nasal spine; $\mathbf{P}$, the most inferior tip of the soft palate; $\mathbf{E T}$, the tip of epiglottis; $\mathbf{E b}$, the base of epiglottis; TT, the most anterior point of tongue tip; CV2sp, the most superior and posterior point on the posterior surface of the second vertebral corpus; CV4ip, the most inferior and posterior point of the fourth vertebral corpus; $\mathbf{S}$, sella; $\mathbf{N}$, nasion; CVi2ip, the most inferior and posterior point of the second vertebral corpus.

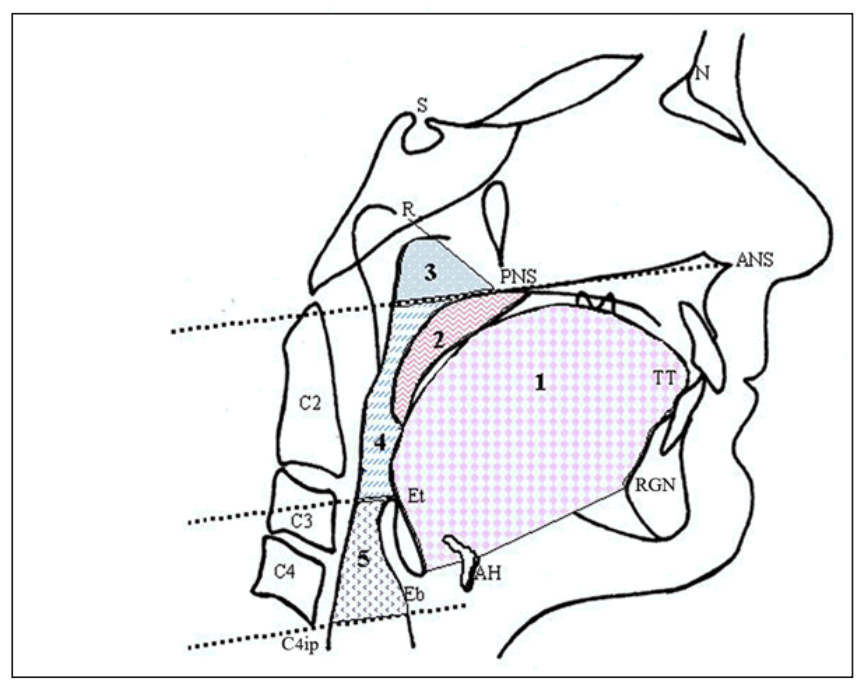

Figure 2. The landmarks and area measurements

(1) Tongue area, the cross-sectional area outlined by the dorsum of the tongue surface and the lines that connect TT, RGN, AH and Eb; (2) soft palate area, it is outlined where it starts and ends at PNS; (3) nasopharynx area, the cross-sectional area outlined by ANS-PNS lin, posterior pharyngeal wall, and the line that connects R and PNS; (4) oropharynx area, the area outlined by the ANS-PNS line, the posterior surface of the soft palate, the postero-inferior surface of the tongue, and a line parallel to ANS-PNS line at Et point; (5) hypopharynx area, it is outlined by the inferior border of the oropharyngeal wall; TT, the most anterior point of the tongue tip; RGN, the most inferior posterior point on the mandibular symphysis; $\mathbf{A H}$, the mst anterior and superior point of the hyoid bone; $\mathbf{E b}$, the deepest point of the epiglottis; ANS, anterior nasal spine; PNS, posterior nasal spine; Et, the tip of epiglottis; C4ip, the most inferior anterior point on the fourth cervical vertebrae. 
position from standing to walking; it was later adopted and modified by Solow and Tallgren (17) while it was defined elsewhere (18). Subjects were asked not to swallow, move their heads and tongues, or contact their teeth lightly while the radiographs were being taken. Radiographs were taken by usual standardized methods.

Gender differences in head posture and upper airway dimensions were determined from lateral cephalograms. Radiographs were traced and measured by 1 investigator (NEŞ). Linear measurements, angular measurements, and landmarks used in our study are shown in Figure 1. Concerning area measurements, the tongue area is measured as the cross-sectional area outlined by the dorsum of the tongue surface and the lines that connect TT, RGN, AH, and $\mathrm{Eb}$. The soft palate area is outlined where it starts and ends at
PNS. The nasopharynx area is measured as the cross-sectional area outlined by the ANS-PNS line, the posterior pharyngeal wall, and the line that connects R and PNS. The oropharynx area is measured as the area outlined by the ANS-PNS line, the posterior surface of the soft palate, the postero-inferior surface of the tongue, and a line parallel to the ANS-PNS line at Et point. The hypopharynx area is outlined by the inferior border of the oropharynx, the posterior surface of the epiglottis, a line parallel to the palatal plane at C4ip, and the posterior pharyngeal wall (Fig. 2).

The area measurements in our study were assessed by digital planimeter (X-Plan 360C, Ushikata, Tokyo, Japan), which is a measuring instrument used to determine the area of an arbitrary 2-dimensional (2D) shape. After tracing the area borders, we used the planimeter to measure each area

Table 1. Statistical comparisons of male and female groups for linear and angular measurements

\begin{tabular}{|c|c|c|c|c|c|c|c|}
\hline \multirow{2}{*}{ Measurements } & Male & \multicolumn{2}{|l|}{$(n=38)$} & Female & \multicolumn{2}{|c|}{$(n=38)$} & \multirow[t]{2}{*}{ p-value } \\
\hline & $\mathbf{X} \pm \mathrm{SD}$ & Min. & Max. & $\mathbf{X} \pm \mathrm{SD}$ & Min. & Max. & \\
\hline MP-AH (mm) & $15.63 \pm 5.09$ & 2.00 & 25.50 & $11.35 \pm 3.93$ & 1.50 & 19.00 & $<0.001$ \\
\hline AH-AH1 (mm) & $-9.78 \pm 5.47$ & -22.00 & 2.00 & $-2.37 \pm 3.53$ & -7.50 & 9.00 & $<0.001$ \\
\hline AH-RGN (mm) & $39.29 \pm 3.85$ & 27.00 & 48.00 & $39.33 \pm 4.81$ & 30.00 & 49.00 & NS \\
\hline C3ia-AH (mm) & $42.58 \pm 3.85$ & 34.50 & 50.00 & $35.32 \pm 3.63$ & 29.50 & 46.50 & $<0.001$ \\
\hline $\mathrm{Ba}-\mathrm{C} 3 \mathrm{ia}(\mathrm{mm})$ & $66.68 \pm 4.88$ & 50.00 & 78.50 & $61.55 \pm 3.50$ & 56.00 & 68.00 & $<0.001$ \\
\hline PNS-P (mm) & $39.65 \pm 3.99$ & 31.50 & 47.00 & $35.68 \pm 3.03$ & 30.50 & 42.00 & $<0.001$ \\
\hline MPT (mm) & $11.15 \pm 1.74$ & 7.50 & 16.00 & $9.65 \pm 1.50$ & 7.00 & 13.50 & $<0.001$ \\
\hline PNS-Et (mm) & $73.41 \pm 5.05$ & 64.00 & 84.00 & $62.68 \pm 5.01$ & 50.00 & 71.00 & $<0.001$ \\
\hline TGL (mm) & $80.54 \pm 5.08$ & 70.00 & 89.50 & $75.97 \pm 4.58$ & 66.00 & 86.00 & $<0.001$ \\
\hline TGH (mm) & $41.76 \pm 3.89$ & 34.00 & 64.50 & $36.61 \pm 3.23$ & 31.00 & 43.00 & $<0.001$ \\
\hline CVTS $^{\circ}$ & $103.49 \pm 6.12$ & 88.00 & 117.50 & $104.88 \pm 7.23$ & 87.00 & 120.00 & NS \\
\hline OPTS $^{\circ}$ & $99.13 \pm 7.57$ & 81.00 & 113.00 & $99.79 \pm 7.75$ & 81.00 & 117.50 & NS \\
\hline SN-MPo & $27.90 \pm 5.29$ & 17.00 & 40.00 & $29.23 \pm 5.65$ & 17.00 & 132.00 & NS \\
\hline $\mathrm{SN} \mathrm{VER}^{\circ}$ & $85.00 \pm 6.03$ & 74.00 & 103.00 & $86.43 \pm 5.63$ & 75.00 & 98.00 & NS \\
\hline MP-VER $^{\circ}$ & $66.84 \pm 6.34$ & 50.00 & 76.00 & $64.12 \pm 5.86$ & 51.00 & 76.00 & NS \\
\hline
\end{tabular}

X: mean, SD: standard deviation, NS: non-significant, Min: minimum, Max: maximum.

Table 2. Statistical comparisons of male and female groups for area measurements

\begin{tabular}{|c|c|c|c|c|c|c|c|}
\hline \multirow{2}{*}{ Measurements } & Male & \multicolumn{2}{|l|}{$(n=38)$} & Female & \multicolumn{2}{|c|}{$(n=38)$} & \multirow[t]{2}{*}{ p-value } \\
\hline & $\mathbf{X} \pm \mathrm{SD}$ & Min. & Max. & $\mathbf{X} \pm \mathbf{S D}$ & Min. & Max. & \\
\hline Tongue Area $\left(\mathrm{mm}^{2}\right)$ & $3442.57 \pm 345.71$ & 280.01 & 4166.07 & $2875.33 \pm 491.4$ & 358.45 & 3536.98 & $<0.001$ \\
\hline $\begin{array}{l}\text { Soft Palate Area } \\
\qquad\left(\mathrm{mm}^{2}\right)\end{array}$ & $325.71 \pm 66.21$ & 197.02 & 611.20 & $245.21 \pm 50.00$ & 162.55 & 366.89 & $<0.001$ \\
\hline $\begin{array}{c}\text { Nasopharynx Area } \\
\left(\mathrm{mm}^{2}\right)\end{array}$ & $258.87 \pm 72.34$ & 120.64 & 448.02 & $273.41 \pm 59.24$ & 138.14 & 414.55 & -NS \\
\hline $\begin{array}{l}\text { Oropharynx Area } \\
\qquad\left(\mathrm{mm}^{2}\right)\end{array}$ & $662.93 \pm 132.14$ & 397.30 & 995.96 & $516.01 \pm 115.22$ & 299.57 & 719.74 & $<0.001$ \\
\hline $\begin{array}{l}\text { Hypopharynx Area } \\
\left(\mathrm{mm}^{2}\right)\end{array}$ & $329.07 \pm 131.84$ & 34.48 & 752.76 & $295.88 \pm 96.17$ & 134.23 & 576.91 & -NS \\
\hline
\end{tabular}

X: mean, SD: standard deviation, NS: non-significant, Min: minimum, Max: maximum. 
3 times and then the mean value was calculated. The mean of the 3 measurements for each area was used for statistical evaluation. Effects of gender differences on craniofacial structures and upper airway dimensions were investigated using a paired Student's t-test. Data were analysed using IBM SPSS v7.5 (IBM, Armonk, NY, USA).

\section{Results}

Linear Measurements (Table 1): Statistically significant differences between genders were observed in vertical (MP-AH, AH-AH1) and horizontal positions (C3ia-AH) of the hyoid bone $(\mathrm{p}<0.001)$. Ba-C3ia measurement showed statistically significant differences between genders $(p<0.001)$. Length of the suprahyoid muscles (AH-RGN) did not show any significant differences between genders. Differences in length and height of the soft palate area (PNS-P and MPT) between genders were statistically significant $(p=0.001)$. PNS-Et linear measurement was statistically significant between genders $(p<0.001)$. Additionally, differences in length and height of the tongue (TGL, TGH) between genders were statistically significant $(p<0.001)$.

Angular Measurements (Table 1): Head posture measurements (CVTS, OPTS, SN-VER, MP-VER) and mandibular plane angle (SN-MP) were not statistically significant between genders.

Area Measurements (Table 2): Differences in the tongue area, soft palate area, and oropharyx area measurements between genders were statistically significant $(p<0.001)$. There were no statistically significant differences observed in measurements of the nasopharynx and hypopharyx areas between genders.

\section{Discussion}

Comparative assessment of head posture and upper airway dimensions in healthy adult male and female subjects with normal vertical dimensions and class I skeletal pattern can provide a standard norm for determining pharyngeal airway structure and gender differences amongst OSA cases. In our study, head posture and upper airway dimensions of healthy 38 adult male and 38 adult female subjects with ideal occlusion and class I skeletal pattern on cephalometric radiographs were investigated.

Statistically significant differences between genders were observed in vertical (MP-AH, AH-AH1) and horizontal positions (C3ia-AH) of the hyoid bone. Linear measurements of the bony structures that encircle the upper airways showed that the hyoid bone was situated more inferiorly and anteriorly in men as opposed to women. By contrast, length of the suprahyoid muscles (AH-RGN) did not show any significant differences between genders. These results indicate that hyocervical relation is affected by gender whereas hyomandibular relation is well balanced in all subjects with normal occlusion and class I skeletal pattern, regardless of gender. Body size differences between men and women could be a reason for this difference. Daniel et al. suggested that, in order to accommodate a larger tongue, a compensatory mechanism may exists only in men; this may be a possible reason for this difference (8). Our results are in agreement with previous studies $(6,8,10,15,19)$.

According to linear measurements, the soft palate was longer and thicker (PNS-P, MPT; $<<0.001$ ), and the tongue was longer and higher in men than in women (TGL,TGH; $\mathrm{p}<0.001$ ). Difference in PNS-Et linear measurement between genders was statistically significant $(\mathrm{p}<0.001)$. Differences in body sizes between genders were similar to the aforementioned linear measurements and statistically significant. These anatomical differences can be explained by the more massive physical structures observed in the necks of men (8). These findings were in agreement with previous studies $(8,14,20)$. Natural head posture - which is controlled by the need to maintain a patent pharyngeal airway - is not only related to respiratory function (12) but it is also releated to other guiding mechanisms, such as sight, hearing, and vestibular orientation $(21,22)$.

In our present study, lateral cephalometric radiographs were obtained in natural head posture. Our study results showed that differences in head posture measurementshead position in relation to the cervical vertebrae (CVTS, OPTS), natural head position (SN-VER), mandibular position in relation to natural vertical line (MP-VER), and mandibular plane angle (SN-MP) - between genders were not statistically significant and that natural head posture was not affected by gender. Unlike our study results, studies conducted by Kollias and Krogstad (10) and Özbek et al. (12) showed higher CVTS measurements in men than in women. In contrast, Sandıkçıoğlu et al. (23) and Fjellvang et al. (21) estimated lower CVTS measurements in men than in women. For women, Kollias and Krogstad (10) and Tallgren and Solow (24) estimated lower CVTS measurements than our study. With regards to OPTS measurements, Huggare and Cooke (25) had lower CVTS measurements in both genders while Sandıkçığlu et al. (23) and Fjellvang et al. (21) only had lower CVTS measurements in men. By contrast, Özbek et al. (12) found that men had higher CVTS measurements. OPTS measurements of male subjects in our study were in concordance with Kollias and Krogstad (10) results; however, there were lower OPTS measurements of female subjects in some studies $(10,19,24)$. Furthermore, some authors (22, 26) obtained lower results in studies where male and female subjects were pooled into group.

With regard to our natural head position measurements (SNVER), Kollias and Krogstad (10) and Huggare and Cooke (25) had higher results for both genders. Özbek et al. (12) estimated higher measurements in men as well. Fjellvang et al. (21) and Sandıkçıoglu et al. (23) were unique in that they recorded lower natural head position in the studies of women; Tallgren and Solow $(19,24)$ had higher measurements than our group. Cole et al. (27) had similar results while Doğan and Ertürk (22) and Solow and Sonnensen (26) estimated higher measurements in their pooled groups. Postural recording methods and / or compositions of samples are possible causes for the varying results of the evaluated studies. However, in all of these studies it was accepted and proven that natural 
head posture was not affected by gender differences.

There were statistically significant differences in the tongue area, soft palate area, and oropharyx area between genders. No statistically significant differences were observed in nasopharynx and hypopharyx area measurements between genders. However, the tongue area, soft palate area, and oropharynx area were wider in men than in women $(\mathrm{p}<0.001)$. Similarly, Huang et al. (28) showed that healthy men had larger pharyngeal areas than healthy women when awake. Our area measurements were in concordance with previous studies $(11,15)$. One possible explanation for this is that small upper airway size in women could be related to body size or differential fat deposition in the neck and around the upper airways. It was demonstrated that there was no correlation between body mass index and pharyngeal size in either men or women (13).

The oropharynx may be one of the most changeable areas of the pharyngeal airway. Linear regression equations for the tongue area, soft palate area, nasopharynx, oropharynx, and hypopharynx indicated that a significant linear relationship existed between the 2D cross-sectional area and the 3-dimensional (3D) volume of the tongue area, soft palate, and nasopharynx. However, such a significant linear relationship did not exist for the $3 \mathrm{D}$ volume of the oropharnyx and hypopharynx (18). By contrast, 3D study and MR study results showed that pharyngeal dimensions were not affected by gender $(8,29)$. Possible reasons for these conflicting results could be study design, subject variables, sample size, imaging techniques, or measurement variables.

In our study, healthy adult subjects with skeletal class I pattern and ideal occlusion were selected so that airway dimensions, hyoid bone measurements, and head posture measurements would reflect only normal healthy anatomic structures without pathology. Additionally, adult subjects were selected in order to eliminate influences of growth. Even though Malkoç et al. stated that cephalometric radiographs were significantly reliable and reproducible in determining airway dimensions, the finding of our study are limited because 3D structures are presented on 2D radiographs, similar to all cephalometric studies. If these limitations are kept in mind, clinicians can still use the data presented to estimate normal soft tissue anatomy. These findings may help develop a better understanding of gender differences. In future pharyngeal airway studies, gender determination should be taken into consideration (30).

\section{Conclusion}

Downward and forward position of the hyoid bone was obtained in men. The hyocervical relation is affected by gender differences whereas the hyomandibular relation is well balanced in the subjects with normal occlusion and class I skeletal pattern, and it was not affected by gender. Natural head posture was not affected by gender differences. The tongue area, soft palate area, and oropharyx area are larger in men than in women. However, there were no statistically significant results obtained for differences in nasopharynx and hypopharyx areas between genders.

\section{References}

1. Strelzow VV, Blanks RH, Basile A, Strelzow AE. Cephalometric airway analysis in obstructive sleep apnea syndrome. Laryngoscope. 1988; 98: 1149-58.

2. Young T, Evans L, Finn L, et al. Estimation of the clinically diagnosed proportion of sleep apnea syndrome in middleaged men and women. Sleep 1997; 20: 705-6.

3. Martin SE, Mathur R, Marshall I, Douglas NJ. The effect of age, sex, obesity and posture on upper airway size. Eur Respir J. 1997; 10: 2087-90.

4. Meredith GM. The airway and dentofacial development. Ear Nose Throat J 1987; 66: 190-5.

5. McNamara JA. Influence of respiratory pattern on craniofacial growth. Angle Orthodontics 1981; 51: 269-300.

6. Adamidis IP, Spyropoulos MN. The effects of lymphadenoid hypertrophy on the position of the tongue, the mandible and the hyoid bone. European Journal of Orthodontics 1983; 5: 287-94.

7. Ceylan İ, Oktay H. A study on the pharyngeal size in different skeletal patterns. American Journal of Orthodontics and Dentofacial Orthopedics 1995; 108: 69-75.

8. Daniel MM, Lorenzi MC, da Costa Leite C, Lorenzi-Filho G. Pharyngeal dimensions in healthy men and women. Clinics (Sao Paulo). 2007; 62: 5-10.

9. Ono T, Lowe AA, Ferguson KA, Fleetham JA. Associations among upper airway structure body position, and obesity in skeletal class I male patients with obstructive sleep apnea. American Journal of Orthodontics and Dentofacial Orthopedics 1996; 109: 625-34.

10. Kollias I, Krogstad O. Adult craniocervical and pharyngeal changes-a longitudinal cephalometric study between 22 and 42 years of age. Part I: morphological craniocervical and hyoid bone changes. European Journal of Orthodontics 1999; 21: 333-44.

11. Kollias I, Krogstad O. Adult craniocervical and pharyngeal changes - a longitudinal cephalometric study between 22 and 42 years of age. Part II: Morphological uvuloglossopharyngeal changes. Eur J Orthod. 1999; 21: 345-55.

12. Özbek MM, Miyamoto K, Lowe AA, Fleetham JA. Natural head posture, upper airway morphology and obstructive sleep apnoea severity in adults. European Journal of Orthodontics 1998; 20: 133-43.

13. Mohsenin V. Gender differences in the expression of sleep-disordered breathing: role of upper airway dimensions. Chest 2001; 120: 1442-7.

14. Gökçe SM, Görgülü S, Gökçe HS, Bengi AD, Sağdıç D. Sağlıklı bireylerde faringeal hava yolu, dil boyutlarının ve hyoid pozisyonunun belirlenmesi. Gulhane Med J 2013; doi:10.5455/gulhane. 39860 .

15. Samman N, Mohammadi H, Xia J. Cephalometric norms for the upper airway in a healthy Hong Kong Chinese population. Hong Kong Med J. 2003; 9: 25-30.

16. Mølhave A. En biostatik Undersøgelse. Menneskets 
Staende stilling teoretisk og statometrisk belyst. With an English summary (A biostatistic investigation of the human erect posture.) Munksgard, Copenhagen, 1958. 'In' Solow B, Tallgren A. Natural head position in standing subjects. Acta Odontologica Scandinavia 1971; 29: 291-607.

17. Solow B, Tallgren A. Natural head position in standing subjects. Acta Odontologica Scandinavia 1971; 29: 291-607.

18. Sahin Sağlam AM, Uydas NE. Relationship between head posture and hyoid position in adult females and males. $\mathrm{J}$ Craniomaxillofac Surg. 2006; 34: 85-92.

19. Tallgren A, Solow B. Hyoid bone position, facial morphology and head posture in adults. Eropean Journal of Orthodontics 1987; 9: 1-8.

20. Lowe AA, Ozbek MM, Miyamoto K, Pae EK, Fleetham JA. Cephalometric and demographic characteristics of obstructive sleep apnea: An evaluation with partial least squares analysis. Angle Orthod 1997; 67: 143-53.

21. Fjellvang H, Solow B. Craniocervical postural relations and craniofacial morphology in 30 blind subjects. Am J Orthod Dentofacial Orthop. 1986; 90(4): 327-34.

22. Doğan S, Ertürk N. The effect of vision on craniocevical posture and its relation to craniofacial and dentoalveolar morphology. Ouintessence International 1990; 21: 401-6.

23. Sandikçioğlu M, Skov S, Solow B. Atlas morphology in relation to craniofacial morphology and head posture. Eur J Orthod. 1994; 16: 96-103.

24. Tallgren A, Solow B. Long-term changes in hyoid bone position and craniocervical posture in complete denture wearers. Acta Odontol Scand. 1984; 42: 257-67.

25. Huggare Jan AV, Cooke MS. Head posture and cervicovertebral anatomy as mandibular growth predictors. European Journal of Orthodontics 1994; 16; 175-80.

26. Solow B., Sonnensen L. Head posture and malocclusions. Eropean Journal of Orthodontics 1998; 20: 685-93.

27. Cole SC. Natural head position, posture, and prognathism: the Chapman Prize Essay, 1986. Br J Orthod. 1988; 15: 22739.

28. Huang J, Shen H, Takahashi M, Fukunaga T, Toga H, Takahashi K, Ohya N. Pharyngeal cross-sectional area and pharyngeal compliance in normal males and females. Respiration. 1998; 65: 458-68.

29. El H, Palomo JM. Airway volume for different dentofacial skeletal patterns. Am J Orthod Dentofacial Orthop. 2011; 139: 511-21.

30. Malkoc S, Usumez S, Nur M, Donaghy CE. Reproducibility of airway dimensions and tongue and hyoid positions on lateral cephalograms. Am J Orthod Dentofacial Orthop. 2005; 128: 513-6. 